SINET: Ethiop. J. Sci., 25(2):253-262, 2002

(C) Faculty of Science, Addis Ababa University, 2002

ISSN: 0379-2897

\title{
INTEGRATED GEOPHYSICAL INVESTIGATIONS TO STUDY THERMAL ZONES AT BOKU VOLCANIC CENTER, MAIN ETHIOPIAN RIFT
}

\author{
Tigistu Haile $^{1}$, Tamiru Alemayehu ${ }^{1}$ and Shimelis Fisseha ${ }^{2}$ \\ ${ }^{1}$ Department of Geology and Geophysics, Faculty of Science, Addis Ababa University, \\ PO Box 1176, Addis Ababa, Ethiopia, E-mail:dgg@telecom.net.et \\ ${ }^{2}$ Ethiopian Institute of Geological Surveys, Ministry of Mines \\ PO Box 2302, Addis Ababa, Ethiopia
}

\begin{abstract}
This paper presents the results of electrical and magnetic surveys carried out over the Boku fumarole sites (Main Ethiopian Rift). On the basis of observed thermal manifestations, surface alterations and geophysical results we suggest that the Boku thermal field is a vapourdominated, dry type geothermal system tapping heat from the shallow acidic magma chamber of Quaternary volcanic rocks of the Rift floor. The cap rock is formed by the self-sealing process through hydrothermal alterations of the Plio-Quaternary volcanic rocks in the area as witnessed by the surface manifestations of calcite and silica that are suggestive of such an environment. The aquifer system consists of the Quaternary Rift floor ignimbrites that are fractured intensively. The necessary supply for the replenishment of the reservoirs is derived from the closed basin system of the Nazareth watershed and/or from the large open irrigated grounds of the Wonji plantation. The investigations have clearly mapped the Quaternary faults that are the major tectonic structures for the passage of the deep-seated vapour to the surface, and the recharging of the geothermal reservoir.
\end{abstract}

Key words/phrases: Boku caldera, hydrothermal alterations, magnetic anomaly, vapour-dominated geothermal systems, vertical electrical sounding

\section{INTRODUCTION}

The Boku thermal centre is located about $5 \mathrm{~km}$ south of Nazareth town within the Main Ethiopian Rift in a region of active axial faulting where the Boku volcano has been built on NE-SW trending system of faults, and subsequently, the volcano has been cut by normal faults of the Wonji Fault Belt (WFB) having a similar trend. Two localities of warm ground and fumarole activity are present in the area in close association with these north-north-east faults (Fig. 1). Steam temperatures of $72-85^{\circ} \mathrm{C}$ have been measured during the field survey and the area has been widely used for its thermal healing. The Boku area is one where the characteristic surface manifestations and all the requisite geological and hydrogeological indications, potential for geothermal energy, are apparent (UNDP, 1973). In fact, it is one of the many areas within the Ethiopian Rift known to posses numerous surface manifestations of underground geothermal energy. The purpose of the multidisciplinary geological and geophysical investigation, carried out in the Boku area, was to elucidate the aerial 
extent, controlling parameters and relation to the major structural features of the thermal centre. The survey attempts also to determine whether Boku can be a reasonable prospect for a small-scale development of thermal extraction centres.

The geothermal potential of the Ethiopian Rift is very high. In the Rift, there exists already a geothermal system which is in its production phase (the first in Ethiopia) at Aluto-Langano (Gianelli and Meseret Teklemariam, 1993). The repeated deep crustal faulting and associated volcanism restrict the hydrothermal activity within the Rift. It is characterized by high thermal anomaly where high geothermal gradients influence the shallow volcanic aquifers such as pyroclastics and basic lava flows. Local thermal anomalies are mostly associated with heat flow from shallow magma chamber. The floor of the Main Ethiopian Rift is known to contain a large number of thermal springs and fumaroles. The well-known spots include Boku, Sodere, Aluto, Wendo Genet, Corbetti, around Lake Shalla, Lake Langano, etc. In these areas the main thermal manifestations are hot water, fumaroles and hot grounds (UNDP, 1973). The main steam conducting fractures are the Wonji faults. These fractures frequently intersect high geothermal gradient areas near the acidic magma chamber. In the MER the main geothermal reservoirs are Pliocene basalts and ignimbrites (Tamiru Alemayehu, 1993; Berhanu Gizaw, 1996; Tamiru Alemayehu and Vernier, 1997). Almost all thermal centres are found in close association with acidic volcanic centres. The deep circulation of groundwater provides a mechanism whereby heat from focused deep source is transferred into diffuse discharge zones.

\section{GEOLOGICAL SETTING}

The major tectonic lines, which are aligned in NE-SW direction in the Rift floor, form numerous local graben and horst structures (Rift-in-Rift structures). The central volcanoes are rooted along these tectonic lines and are characterized by collapsed calderas, among which the Boku caldera occupies the southern part of Nazareth city in the Main Ethiopian Rift (MER). The volcanic eruption and emplacement of the products took place 0.8 million years (m.y.) ago (Alula Damte et al., 1992). The volcanic products from the Boku volcano can be grouped as alkaline and peralkaline rhyolite lava domes, flows, and pyroclastic falls, which cover the floor complex ignimbrite deposits. After the emission of these products and collapse of the caldera, intra-caldera products such as scoria cones with associated basaltic lava flows cover the central caldera. The Boku ridge forms the highest elevation in the area rising from $1600 \mathrm{~m}$ to $1875 \mathrm{~m}$ above sea level. This young volcano has been repeatedly dissected by the recent deep and extensive late Quaternary faults, which are part of the WFB (Mohr, 1971). In this regard the time coverage for the faulting at the Boku reaches as much as the age of the volcano (0.8 m.y., Alula Damte et al., 1992) or even younger considering that the WFB took place 1.6 my ago (Meyer et al., 1975).

The main lithological units identified in the area, from older to younger, are the following (Fig. 1): Rift floor ignimbrites; slightly welded tuffs; unwelded tuffs; rhyolitic lava flows; pumice fall deposits; obsidian flows, and basaltic lava flows and scoria. These lithologic units are not laterally continuous and show variations in thickness. 


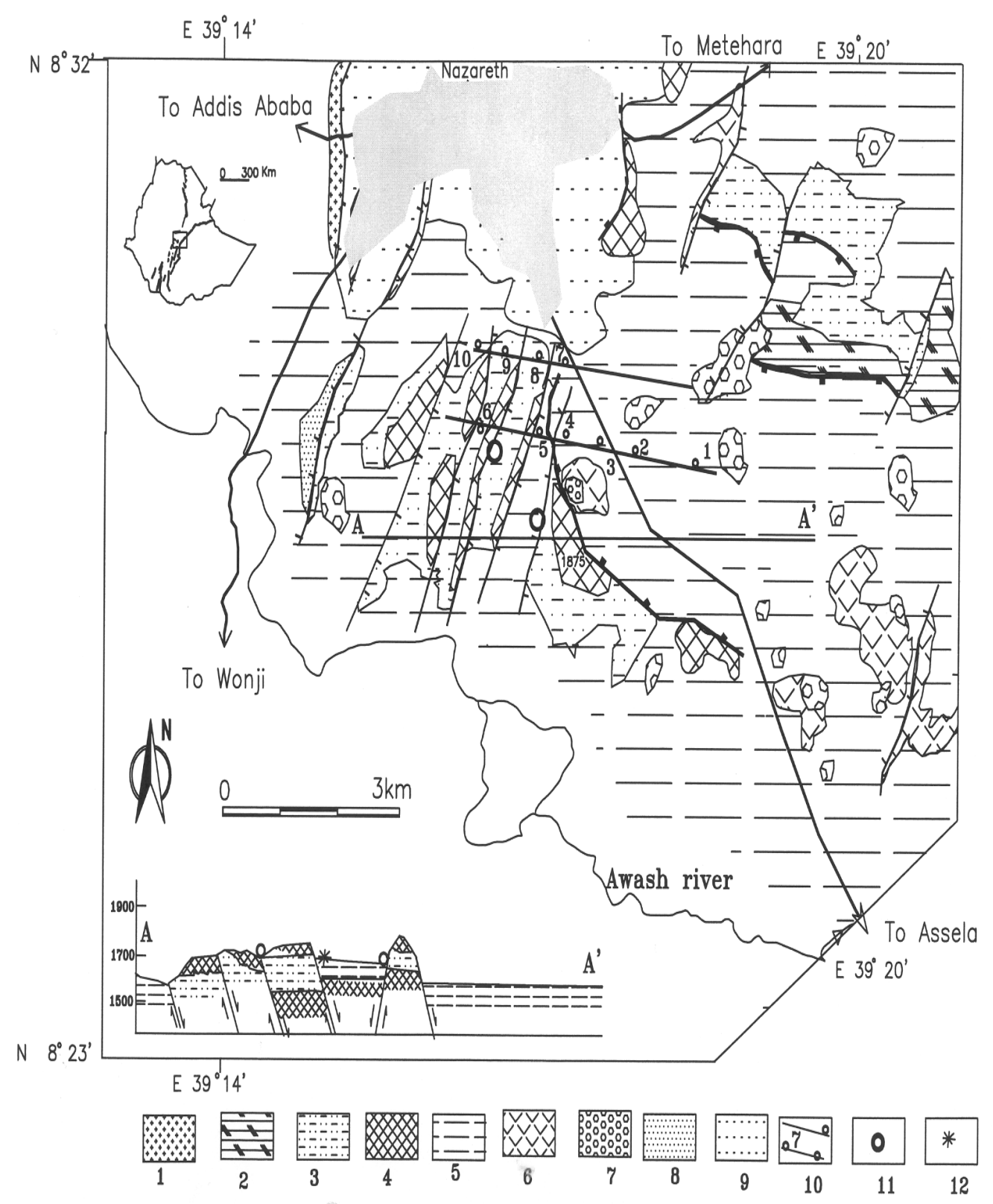

Fig. 1. Geological map of Boku Area (Modified after Alula Damte et al., 1992). 1- Rift floor ignimbrites, 2- Slightly welded tuffs, 3- Pumice fall deposits, 4- Rhyolitic lava flows, 5Unwelded tuffs, 6- Basaltic lava flows, 7- Scoria, 8- Lacustrine deposits, 9- Alluvial deposits, 10- Resistivity profile line and VES points, 11- Active thermal centres, and 12Proposed well site. 


\section{Rift floor ignimbrites}

The rift floor ignimbrites are the oldest outcropping unit in the area. The main outcrops are found just west of Nazareth town having elongated outcrops and bounded by faults. The ignimbrites are strongly welded and massive. The total observed thickness is about $100 \mathrm{~m}$ with the K/Ar age of $1.7 \mathrm{Ma}$ (Alula Damte et al., 1992). According to the regional stratigraphy, rift floor ignimbrites are believed to be the basal rocks below the Boku volcanic products.

\section{Slightly welded tuffs}

This unit is rich in pumice clasts and lithic fragments. The tuff has brown colour and outcrops along the eastern rim of the Boku caldera. The unit has a thickness of about $80 \mathrm{~m}$.

\section{Rhyolitic lava flows}

The rhyolitic lava flows occur as a basal layer on the western rim of the caldera. These flows are grey in colour and porphyritic in texture. The outcrop is limited around the vent. This unit confines the pumice fall and the obsidian flows and forms steep slopes around the rim.

\section{Pumice fall deposits}

Stratigraphically, the deposit covers the lower rhyolitic lava flow and is areally very extensive. In the hydrothermally active areas, it is completely altered. The pumice fall deposit forms gentler slope even far away from the caldera with the exposed thickness of about $4.5 \mathrm{~m}$.

\section{Obsidian flows}

These flows are limited around the caldera rim and have characteristic black colour. The flows are intensively fractured and at some places weathered to the state of perlite. The unit is unmapable in the considered scale.

\section{Unwelded tuffs}

The unwelded tuffs cover the entire plain areas of the region. The unit has small amount of pumice fragments, some dark coloured rock fragments as much as $4 \mathrm{~cm}$ in diameter, and is generally dominated by ash. Since the unit is very loose, the surface runoff has formed deep gullies all over the farmlands.

\section{Basaltic lava flows and scoria}

These units are the result of post caldera eruption and are localized within the caldera. The basaltic lava flows are vesicular in texture and some of them are filled with secondary minerals. In some outcrops basaltic lava flows underlie the scoria deposits. 


\section{THE BOKU THERMAL CENTRES}

On the Boku ridge, the rhyolitic lava flows show flow banding and are intensively fractured favouring both shallow infiltration and uprising of steam. According to Tamiru Alemayehu and Vernier (1997), the high temperature of groundwater at shallow depth around Nazareth is likely due to the presence of high temperature gradient at shallow depth that was defined as $1^{\circ} \mathrm{C}$ increase for every $6 \mathrm{~m}$ of depth $\left(0.17^{\circ} \mathrm{C} / \mathrm{m}\right)$.

The permeable aquifers forming the reservoir must therefore have a hydraulic continuity with the large recharge areas for the rainwater to be available in continuous supply. Possible sources that can be attributed to the Boku fumaroles are waters of the Nazareth closed hydrographic basin that forms stagnant pool, and water from the irrigated plains of the Wonji plantation, which has to be confirmed by isotopic studies. Meteoric waters may also penetrate downwards through faults at the sites where there are no uprising hot fluids. The recharging water should continually be flowing into the aquifer to balance any natural loss occurring at points of the surface as a fumarole. Until these days no proper exploitation of the steam has been carried out in the area with the help of boreholes.

The importance of the Boku caldera both as a route for recharge of water and discharge of hot fluids should not be underestimated. It is wise to note that a caldera, like the Boku, has been subjected to such intense mechanical and thermal stress that complex faulting will have caused the formation of extensive permeability, which, with time, may become covered by a cap rock as in the case of a graben. The fact that voluminous acidic magma has been extruded from Boku volcano in relatively recent geologic time means that there is still a large store of residual heat beneath the fractured zone.

The hydrothermal alteration zones apparent on the ground extend for about $200 \mathrm{~m}$ along a normal fault down-thrown to the northeast (Fig. 1). About $1 \mathrm{~km}$ east of this, another zone of hydrothermal alterations up to $100 \mathrm{~m}$-wide and extending for about $300 \mathrm{~m}$ along another fault down-thrown to the southwest is apparent. The discharge of steam is controlled by the young faults and fractures. The main indications of long-lived strong hydrothermal activity are the deposits of calcium carbonate and quartz.

At present a warm ground is restricted to a narrow zone along NE-SW aligned normal faults line at the western shoulder of the caldera. Quartz and calcite are observed to seal the fracture and the rock is altered forming kaolin. The surface manifestation of these alteration zones is indicative of hydrothermal process (Economides and Ungemach, 1987). These hydrothermal alterations are suggestive of the fact that the thermal field is a self-sealing type due to the deposition of secondary minerals so that at present the steam centres are localized along deep fracture lines. 


\section{GEOPHYSICAL INVESTIGATIONS AND RESULTS}

A large scale geothermal exploration operation essentially aims at locating the geothermal field or low grade aquifer; decision as to whether a field, if found, is semithermal or hyperthemal; determine whether the hyperthermal field, if located, is steam or water dominated, and define as closely as possible the location, the area, depth and probable range of temperatures of any located field or low grade aquifer (Mediav, 1970; Banwell, 1970; Giancaro, 1973).

The choice of the geophysical method to be used for surveying a particular potential geothermal site depends upon the local geological conditions and the objectives assigned to geophysics. One method is less likely to solve all problems encountered in geothermal exploration solely (as is the case in all other problems requiring inputs from geophysical work), and it is in general recommended that at least two methods be used, based on different criteria and parameters (Rybach and Muffler, 1981; Economides and Ungemach, 1987).

The results in this paper are based on two methods, namely electrical resistivity survey and magnetic survey. The small aerial extent of the thermal manifestations, accessibility, availability of equipment, financial limitations and the initial objectives assigned to geophysical work - that of delineating the major structural controls and defining the type of geothermal system in operation at Boku have warranted the use of these two methods. As to the density of the measuring points, the standard sampling values of 2-4 stations $/ \mathrm{km}$ for the electrical sounding surveys, and 100 stations $/ \mathrm{km}$ for the magnetic surveys, envisaged in geothermal prospecting, have been used.

\section{Electrical resistivity surveys}

The resistivity of a geologic horizon depends on a number of parameters, the most important of which are porosity, salinity of interstitial fluid, and temperature. The effect of temperature change is the greatest especially at low temperatures $\left(<100^{\circ} \mathrm{C}\right)$ and becomes small for temperatures $>200^{\circ} \mathrm{C}$. In deeper parts of a hydrothermal system, the resistivity is more affected by porosity and salinity than by variations in temperature, where the effect is more pronounced in horizontal profiling where lateral variations in resistivity are mapped. Therefore, at Boku the Schlumberger vertical electrical sounding (VES) and axial dipole-dipole profiling techniques have been applied for mapping both the vertical and horizontal variations in resistivity. The results of the dipole-dipole profiling surveys, along with gravity, temperature, and time domain electromagnetic (TDEM) sounding surveys will be presented in another contribution.

Superimposed on Figure 1 are shown the two traverses along which these surveys have been carried out. A total of ten VES surveys were done six on the first and longest profile and four on the second. The spacing between the VES 
points was chosen to be $500 \mathrm{~m}$ whenever the topographic conditions permitted to maintain this station separation. The two traverses are separated by one kilometre, and the soundings were carried out with maximum $\mathrm{AB} / 2$ of $500 \mathrm{~m}$ on most and $\mathrm{AB} / 2$ of $750 \mathrm{~m}$ on some sounding points. Profiling surveys were also carried out on both traverses. The traverse and the survey points were so chosen to start well within the Boku caldera and extend over the currently active Boku thermal centre.

The Briggs and Stratton AC generator, the heavy duty Scintrex TSQ-3 Low Frequency Square Wave Transmitter and the IPR-10 Receiver system with the associated accessories were used for both the sounding and profiling surveys. The data from these surveys were analyzed using the standard GEOSOFT (SUSHI, version 2.00) software and sample results of the VES analysis, for traverse $2 \mathrm{a}$, are presented in Figure 2 for discussion in this paper. The Figure gives the interpreted geoelectric section along VES points 7, 8 and 9.

\section{Magnetic surveys}

Magnetic surveys are commonly used exploration tools for their ability in lithologic differentiation of the basement and their ability to highlight structural features like faults, grabens and horsts. In geothermal field surveys this technique is found to be even more attractive and of high potential, as it is suited for mapping hydrothermal alteration zones related to the presence of a geothermal reservoir. These are often characterized by the alteration of magnetite to pyrite, and therefore give magnetic responses less than that of unaltered zones. The rapidity with which the measurements can be made and the low cost of operation were additional justifications for using this method at Boku in the present study.

Accordingly, magnetic surveys were carried out using the IGS-2 Integrated Geophysical System and total field values at 10-meter intervals were measured along three profiles. Two of these profiles are the same as the profiles over which electrical surveys were done, and the third traverse was selected mid-way between these two (500 $\mathrm{m}$ from traverse 1$)$. The total field plots along traverse two are given in Figure 2b.

\section{DISCUSSION}

The geoelectric section from the VES data given in Figure 2a is for the profile passing through VES points 7,8 and 9. Based on the resistivity ranges available and the stratigraphic succession of the area obtained from geologic studies, the section has been interpreted to mainly consist of a four to five layer earth structure. A top layer of alluvial cover with an approximate constant thickness of $0.9 \mathrm{~m}$ along the traverse overlies a second layer of about $2 \mathrm{~m}$ thickness, with resistivity values ranging from $40 \Omega \mathrm{m}$ to $82 \Omega \mathrm{m}$ and constitutes the ash deposit layer. A third layer of considerably large but varying thickness at 
various points along the traverse appears as the dominant lithologic unit in the area. This is interpreted as the pumice-fall deposit. This layer is missing at depth around VES points 7 and 9 but is continuous to large depth on both sides of VES 8.

Below this third layer is a highly resistive (980-984 $\Omega \mathrm{m}$ ) rhyolitic lava mapped around VES points 7 and 9 constituting the basement layer. It is probable that this layer forms part of the lava flow that is observed from surface geological mapping as shown to outcrop at different locations on the geologic map. The fifth layer, especially mapped around VES 8 and not shown in the section, is a layer of decreasing resistivity with depth (120-52 $\Omega \mathrm{m}$, around VES 8) extending to depths as far as the current penetration could go with this survey, to depths in excess of $200 \mathrm{~m}$. Along this traverse and within the thick layers are small lenses that have resistivities ranging from small to moderate values and the presence of these lenses may affect the general resistivity trend of the geoelectric section.

From the magnetic profile plot given in Figure $2 b$ it is seen that relatively smooth and low values of total magnetic field are recorded along the same traverse except at the two locations around VES points 7 and 9. The magnetic field variations are in good conformity with the electrical measurements in that they accurately depict the location of the major subsurface structural units, specifically the structural contacts at depth. The low, almost smooth, magnetic anomalies shown indicate the presence of highly hydrothermally altered rock units that are devoid of elements with magnetic properties.

\section{CONCLUSIONS}

The data and information obtained from this investigation lead us to suggest that Boku is a vapour dominated dry type geothermal field with characteristics (in which) steam is produced in saturated state with steam temperatures generally $>150^{\circ} \mathrm{C}$. The cap rock is most probably produced by a self-sealing process through the alteration of acidic volcanic rocks and deposition of secondary minerals. The presence of silica and calcite are indication of the presence of strong hydrothermal activity. The main conduits for the propagation of heat from the deep-seated thermal sources are the Quaternary faults and fractures. The results of representative geoelectric and magnetic profile sections clearly show these structures. In summary, the ideal borehole sites for tapping the steam are along the fault zones or zones of crossing of the fault systems are shown on the geological map in Fig. 1. 
a)

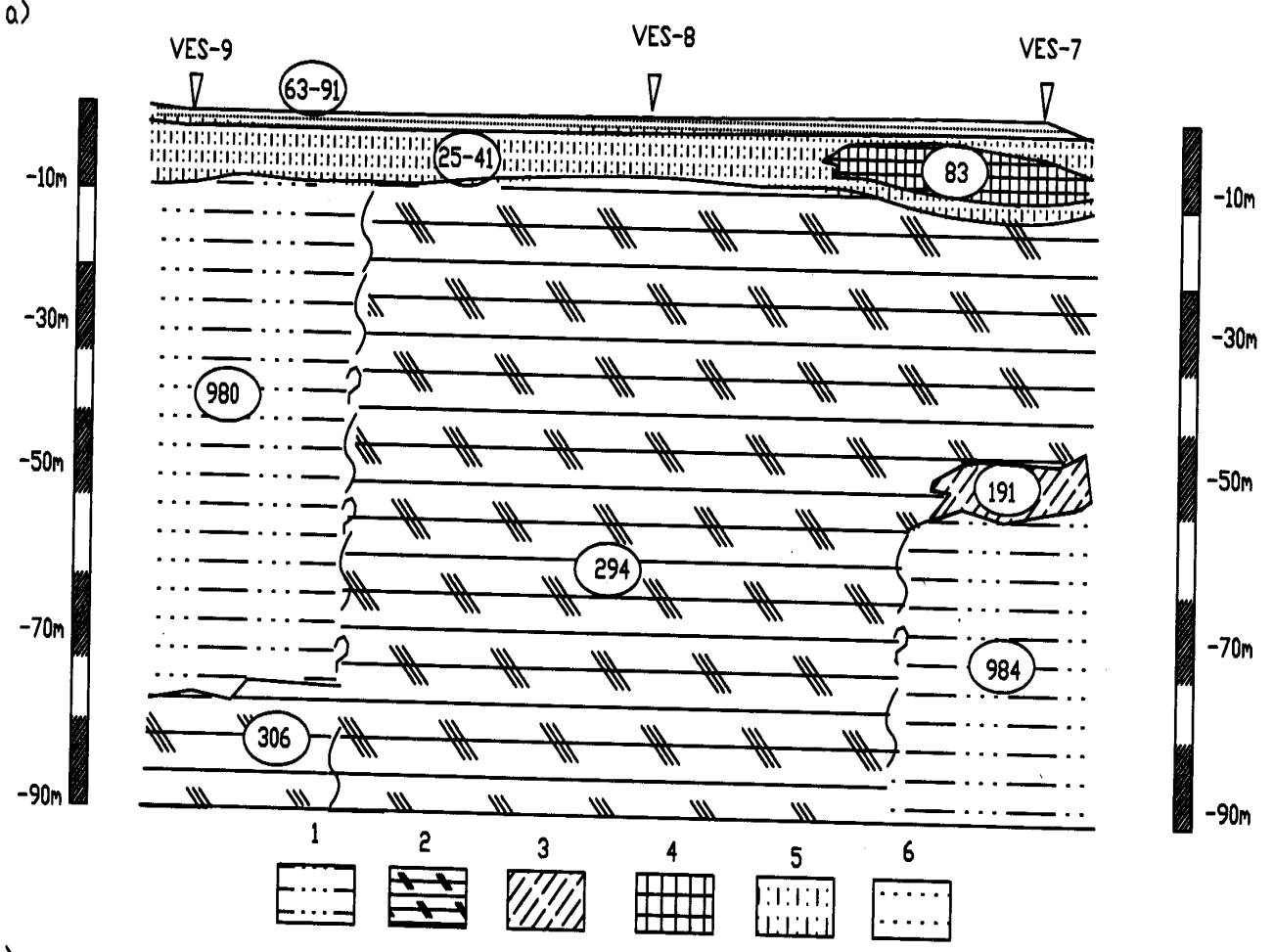

b)

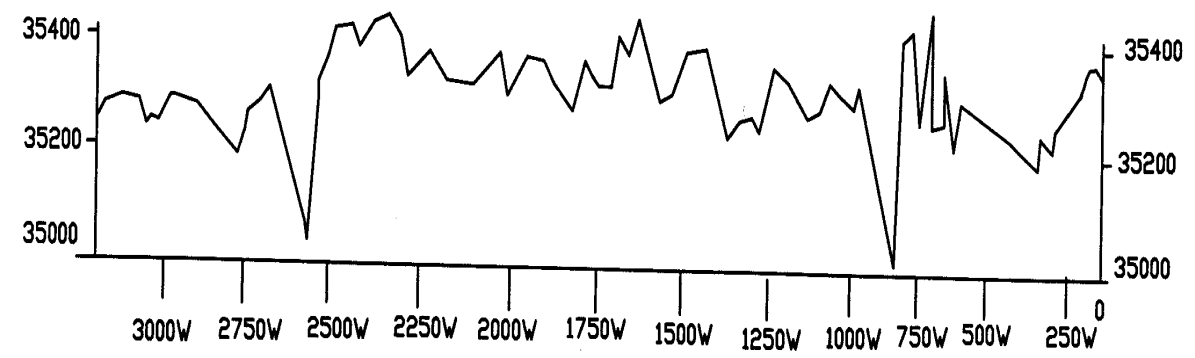

Fig. 2. a) Geoelectric section for VES 7,8 and $9(\Omega \mathrm{m})$ and b) magnetic profile plot around VES points 7 and 9 (gamma). 1- Rhyolitic lava flows; 2- Unwelded tuffs; 3- Altered basaltic lava flows; 4- Fresh basaltic lava flows; 5- Pumice deposits; 6- Alluvial deposits.

The observed decrease in resistivity at greater depth suggests that geophysical methods with larger depths of penetration, extending to the depth of the heat and surface water interacting zone, are required to map the aquifer system. In addition, geochemical and isotopic studies (such as deuterium, tritium, 
oxygen) are also proposed to identify whether the source of the recharge is of meteoric or juvenile origin.

\section{REFERENCES}

1. Alula Damte, Boccaletti M., Mazzuoli R, Getaneh Assefa. and Tortorici, L. (1992). Geological map of the Nazareth Dera Region (Main Ethiopian Rift). Scale 1:50 000. S.E.L.C.A. Florence, Italy.

2. Banwell, C.J. (1970). Geophusical techniques in geothermal exploration. In: Proceedings of the UN Symposium on the Development and Use of Geothermal Resources. Geothermics Special Issue 1, 2. Pisa.

3. Berhanu Gizaw (1996). Aluto-Langano geothermal field, Ethiopian Rift valley: Physical characteristics and the effects of gas on well performance. Geothermics. 22:101-116.

4. Economides, M.J. and Ungemach, P.O. (1987). Applied Geothermics. John Wiley and Sons. p. 237.

5. Giancaro, F. (1973). The structure and behaviour of geothermal fields. In: Geothermal Energy: Review of Research and Development, UNESCO, Paris, pp. 61-69.

6. Gianelli, G. and Meseret Teklemariam (1993). Water-rock interaction processes in the Aluto-Langano geothermal field (Ethiopia). J. Volcan. Geothermal. Res. 56:429-445.

7. Mediav, T. (1970). Application of electrical resistivity and gravimetry in deep geothermal exploration. In: Proceedings of the UN Symposium on the Development and Use of Geothermal Resources, Pisa, Geothermics Special issue 1,2(1974).

8. Meyer, W., Pilger, A., Rosler A. and Stets, J. (1975). Tectonic evolution of the northern part of the Main Ethiopian Rift in Southern Ethiopia. In: Afar Depression of Ethiopia, pp. 352-362, (Pilger A., and Rosler A., eds). IUCG Sci. Rep. 14,.Stuttgart.

9. Mohr, P.A. (1971). The Geology of Ethiopia, Addis Ababa University Press, p. 268.

10. Rybach, L. and Muffler, L.J.P. (1981). Geothermal Systems: Principles and Case Histories. John Wiley and Sons, p. 359.

11. Tamiru Alemayehu (1993). Preliminary analysis in the availability of groundwater in Ethiopia. SINET: Ethiop. J. Sci. 16:43-59.

12. Tamiru Alemayehu and Vernier, A. (1997). Conceptual model for Boku hydrothermal area (Nazareth), Main Ethiopian Rift. SINET: Ethiop. J. Sci. 20(2):283-291.

13. UNDP Technical Report (1973). Investigation of geothermal resource for power development, Ethiopia. Geology, geochemistry and hydrogeology of hot springs of the east African Rift system within Ethiopia. Ethiopian Geological Survey, Addis Ababa, Ethiopia. 